\title{
Maturity, growth and natural mortality rate of the introduced fish Parachromis managuensis (Perciformes: Cichlidae) in the semiarid region of Brazil
}

Maturidade, crescimento e taxa de mortalidade natural do peixe introduzido Parachromis managuensis (Perciformes: Cichlidae) na região semiárida do Brasil

\author{
Amanda Graziele Araújo Resende ${ }^{1,2 *}$ (D), Elton José de França ${ }^{3}$ (D), \\ Cícero Diogo Lins de Oliveira ${ }^{1,2}$ (D) and Francisco Marcante Santana ${ }^{1,2}$ (iD
}

${ }^{1}$ Laboratório de Dinâmica de Populaçóes Aquáticas - DAQUA, Unidade Acadêmica de Serra Talhada - UAST), Universidade Federal Rural de Pernambuco - UFRPE, Avenida Gregório Ferraz Nogueira, s/n, José Tomé de Souza Ramos, CEP: 56909-535, Serra Talhada, PE, Brasil

${ }^{2}$ Programa de Pós-graduação em Biodiversidade e Conservação - PGBC, Unidade Acadêmica de Serra Talhada - UAST, Universidade Federal Rural de Pernambuco - UFRPE, Avenida Gregório Ferraz Nogueira, s/n, José Tomé de Souza Ramos, CEP: 56909-535, Serra Talhada, PE, Brasil

${ }^{3}$ Laboratório de Ecologia e Sistemática de Peixes - LAESP, Unidade Acadêmica de Serra Talhada UAST, Universidade Federal Rural de Pernambuco - UFRPE, Avenida Gregório Ferraz Nogueira, s/n, José Tomé de Souza Ramos, CEP: 56909-535, Serra Talhada, PE, Brasil

*e-mail: amandagraziele019@gmail.com

Cite as: Resende, A.G.A. et al. Maturity, growth and natural mortality rate of the introduced fish Parachromis managuensis (Perciformes: Cichlidae) in the semiarid region of Brazil. Acta Limnologica Brasiliensia, 2020, vol. 32, e29.

Abstract: Aim: The present study aimed to estimate the sexual maturity, growth and mortality rates of the jaguar guapote, Parachromis managuensis, an introduced fish species in the Brazilian semiarid region. Methods: Specimens were collected between December 2015 and November 2016, in a dam at Serra Talhada municipality, Pernambuco, where the species was abundant. Results: In total, 520 individuals were analyzed, with total lengths (TL) varying between 23 and $240 \mathrm{~mm}$. Length at sexual maturity varied between 130.87 and $140.68 \mathrm{~mm}$ TL (Mean $=135.78 \mathrm{~mm} \mathrm{TL}$ ). Through the modal progression of monthly frequency distributions, the following growth parameters were obtained according to the von Bertalanffy model: $L_{\infty}=341.40 \mathrm{~mm}, k=0.840$ and $t_{0}=-0.035$ year $^{-1}$. Ages varied from 0.05 to 1.41 year, and an age at first maturity between 0.48 and 0.53 year (Mean $=0.51$ year), with the largest part of the sample (72.64\%) made of adult individuals. Natural mortality rates $(M)$ were estimated from three different methods, varying between 1.53 and 3.04, with a mean of 2.27. Conclusions: P. managuensis shows fast growth and maturation and high natural mortalities, which grants it biological advantages when compared to native species from the same trophic level in the area.

Keywords: Jaguar Guapote; Northeastern Brazil; length-weight relationship; age structure.

Resumo: Obietivo: O presente estudo teve como objetivo estimar a maturidade sexual, o crescimento e as taxas de mortalidade do peixe introduzido na região do semiárido brasileiro, o jaguar guapote, Parachromis managuensis. Métodos: Os exemplares foram coletados entre os meses de Dezembro de 2015 e Novembro de 2016, em um açude do município de Serra Talhada, Pernambuco, onde a espécie é abundante. Resultados: Um total de 520 indivíduos foram analisados, 
com comprimentos totais $(C T)$ que variaram entre 23 e $240 \mathrm{~mm}$. O comprimento de maturação sexual variou entre 130,87 e 140,68 mm CT (Média = 135,78 cm CT). Através da progressão modal das distribuiçóes de frequência mensais, foram obtidos os seguintes parâmetros de crescimento segundo o modelo de von Bertalanffy: $L_{\infty}=341,40 \mathrm{~mm}, k=0,840$ e $t_{0}=-0,035 \mathrm{ano}^{-1}$. As idades variaram entre 0,05 a 1,41 ano, com uma idade de primeira maturação entre 0,48 e 0,53 ano (Média = 0,51 ano), sendo a maior parte da amostra (72,64\%) formada por indivíduos adultos. Taxas de mortalidade natural $(M)$ foram estimadas à partir de três diferentes métodos, e variaram entre 1,53 e 3,04, com uma média de 2,27. Conclusão: P. managuensis possui crescimento e maturação rápida e altas mortalidades naturais, o que lhe dá vantagens biológicas em relação a espécies nativas do mesmo nível trófico na área.

Palavras-chave: Jaguar Guapote; Nordeste do Brasil; relação peso-comprimento; estrutura etária.

\section{Introduction}

Among the anthropic actions, the introduction of non-native species has led to ecological significant events, biological invasions, which can affect biodiversity from the genetic to the landscape level (Vitule, 2009; Vitule \& Prodocimo, 2012). These species introductions and translocations are among the main adversities that affect freshwater fish conservation, since non-native species compete for space and food. Therefore, they cause imbalances in ecological niches, altering the food chain dynamics and, consequently, nutrient transfer (CollaresPereira \& Cowx, 2004; Amador et al., 2009).

In Brazil, several non-native fish species have been reported in different environments (Bittencourt et al., 2014; Gubiani et al., 2018; Patoka et al., 2018). Among these species is the jaguar guapote, Parachromis managuensis (Gunther, 1867), a member of the Cichlidae Family. Native to the rivers of Central America, between Honduras and Costa Rica (Bussing, 2002), it has been introduced in many countries, such as Brazil (Agasen et al., 2006; Rosana et al., 2006; Barros et al., 2012; Hamiyati et al., 2019), including the Northeastern semiarid, where species introduction may have been accidental (França et al., 2017; Ramos et al., 2018). P. managuensis is widely distributed in Brazil, with reports of its use in pisciculture, fish stocking and aquarium activities (Barbosa et al., 2006; Magalhães \& Jacobi, 2010; Barros et al., 2012). This species is described as potentially invasive, displaying a series of key characteristics such as fast maturity, resistance to environmental changes, besides displaying a territorial aggressive behavior, with a mainly piscivorous carnivorous diet (Agasen et al., 2006; Barbosa et al., 2006), which can make it successful in competition with native fishes. For these reasons, it is listed on the invasive species database of the Inter-American Biodiversity Information Network (2019). For these reasons, given adequate environmental conditions, $P$. managuensis can establish itself and cause ecological damages to native species.

The caatinga is a biome exclusive of Brazil and part of this biological heritage is found only in Northeast of country. It is a heterogeneous biome, with great diversity of fauna and flora, and with a high degree of endemism of species. Despite its biological importance, the caatinga still has a low priority and insufficiency in terms of scientific studies (Leal et al., 2005). The Caatinga although exhibiting a dry climate, harbors many springs, such as lakes, dams and rivers, where a large diversity of species dwells. Studies on this diversity revealed that the semiarid region has 386 fish species, out of which 371 are native, 203 are considered endemic to the ecoregions where the Caatinga occurs, 15 are introduced from other basins, and 33 are threatened at some level (Lima et al., 2017). This fact demonstrates the urgency of studies that clarify the biological consequences of non-native species to native and endemic species in this region, which is already in need of studies and has been extensively devastated.

In this context, studies that contribute to the knowledge on population dynamics of non-native fishes aid in the development of risk analyses for these species. Thus, studies on age and growth are important to subsidize data on species population dynamics, since information regarding age structure of a fish population favours the interpretation of growth and survival variability, enabling the comprehension of factors that condition recruitment success (Jones, 1992). For these reasons, this study aimed to determine the population parameters of sexual maturity, growth and natural mortality rates of $P$. managuensis in a reservoir of the Brazilian semiarid region.

\section{Material and Methods}

The study site is at the Brazilian semiarid region, with shows particularities, such as the high spatial and temporal variation in precipitation, high 
evapotranspiration potential, a deficit in water balance, and deciduous vegetable cover known as "Caatinga" (Barbosa et al., 2012; Moura et al., 2007). Sampling took place at the Saco I dam, with a water capacity of 36 million $\mathrm{m}^{3}$, located at the Serra Talhada municipality, in the sertão mesoregion of Pernambuco state. The study site belongs to the Pajeú river basin, considered the state's largest, with an area of $16685.53 \mathrm{~km}^{3}$ and an intermittent river regime (APAC, 2018).

Specimens of $P$. managuensis (Figure 1) were collected monthly at the Saco I dam, from December 2015 to November 2016, with the use of 1.5 and $2.2 \mathrm{~m}$ cast nets with mesh openings from 15 to $20 \mathrm{~mm}$, and $5-30 \mathrm{~m}$ trawl nets with a $5 \mathrm{~mm}$ mesh. For each captured specimen, total (TL) and standard (SL) lengths were measured, as well as total weight (TW), with the use of a scale with a $0.0001 \mathrm{~g}$ precision.

The weight-length relationship ( $T W-T L)$ for $P$. managuensis was estimated following the potential equation $T W=a^{*} T L^{B}$, where $a$ is the coefficient of proportionality and $b$ is the angular coefficient related to the species way of growth (Le Cren, 1951). The weight-length relationship analyzes the differences in growth related to the increase in weight or length, and can assume isometric or allometric characteristics. The existence of isometry $(b \approx 3)$, occurs when the increase in weight accompanies the growth in length, if not, the relationship is allometric, can be positive when the growth in weigth is greater than length $(b>3)$ or negative when the growth in length is greater than weigth $(b<3)$ (Froese, 2006). The angular coefficient obtained was submitted to a Chi-square test $(\chi 2)$, aiming to observe differences of the $b$ value calculated with 3 (isometry). The linear relationship between total and standard lengths $\left(T L=a+b^{*} S L\right)$ was also calculated for the entire sample.

The length at maturity was estimated according to two methods. The first method consists of

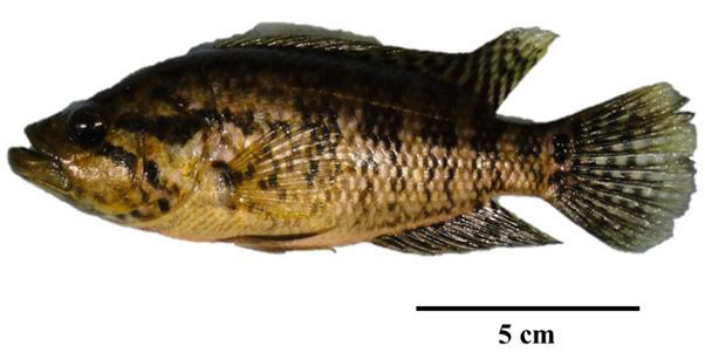

Figure 1. Specie P. managuensis collected in at the Saco I dam, Pernambuco-Brazil. gonad macroscopic analyses, that were performed to identify specimens sex and maturity (young or adults), according to maturity scale for fishes described by Vazzoler (1996). These information allowed to estimate the length at which $50 \%$ of individuals are adults $\left(L_{50}\right)$ according to the equation by King (1995): $P=1 /\left[1+e^{-a_{x}^{*}\left(T L-L_{50}\right)}\right]$, where $P$ is the proportion of adult individuals per total length (TL) class and $a_{x}$ is the equation parameter.

The second method used to determine length at sexual maturity was a polyphasic model divided in two stanzas, in which each stanza describes by a power function. The length-weight relationship and a logistic function for the $a$ and $b$ parameters of Huxley (1924) was used to describe relative growth and a change in growth pattern (stanzas) in the life history of species. The power function: $y=f(a) x^{f(b)}$, was divided in two stanzas ( 1 and 2 for each length - weigth coefficients $a$ and $b): f(a)=a_{1}+\left(a_{2}-a_{I}\right) /\left(1+e^{R s c(a) \cdot(x-L s c)}\right)$ and $f(b)=b_{1}+\left(b_{2}-b_{1}\right) /\left(1+e^{R s c(b) .(x-L s c)}\right)$ where, $R_{s c}(a / b)$ is the rate of coefficient changes between stanza 1 and 2 , and $L_{s c}$ is the length at the stanza changing point, which was considered as the length at maturity (Fontoura et al., 2010; Freitas et al., 2016). To estimate the parameters for the two methods, functions were adjusted and parameters estimated through the Solver routine available on the Microsoft Excel software using minima square, and the bootstrap analysis to calculate confidence intervals.

Growth parameters of the von Bertalanffy (1938) model were estimated from the following equation: $L_{t}=L_{\infty}\left[1-e^{-k\left(t-t_{0}\right)}\right]$, where $L_{t}$ is the length at age $t, L_{\infty}$ is the species asymptotic or theoretical maximum length; $k$ is the growth coefficient and $t_{0}$ is the theoretical age at length zero. To estimate these parameters, the monthly modes from the length frequency distribution were used through software ELEFAN I (Eletronic Lengths-Frequency Analysis) (Pauly et al., 1981), through a modal progression analysis, performed on the FISAT software (FAO ICLARM Stock Assessment Tools) (Gayanilo et al., 1997). The value for $t_{0}$ was estimated based on the equation described by Pauly (1979):

$$
\log \left(-t_{0}\right)=-0.3922-0.2752 x \log \left(L_{\infty}\right)-1.038 x(k) \text {. }
$$

The population age structure was estimated based on its total length (TL), from the inverted Von Bertalanffy equation:

$$
t(L)=t_{0}-\frac{1}{k} * \ln \ln \left(1-\frac{T L}{L_{\infty}}\right) .
$$


Natural mortality rates $(M)$ for the species were estimated based on three methods:

Hoenig (2005): $\ln M=1.46-1.01$ lnt $_{\max }$

Pauly (1980):

$\ln \ln M=-0.0066-\left(0.279 \ln \ln L_{\infty}\right)+(0.65431 \ln \ln k)+(0.4634 \ln \ln T)$

Rikhter \& Efanov (1976): $M=\frac{1,521}{t_{50} 0.72}-0.155$

In which, $t_{\max }$ is the highest age in the sample; $T$ is the average water temperature $\left({ }^{\circ} \mathrm{C}\right)$, and $t_{50}$ corresponds to the average age at first maturity.

\section{Results}

In total, 520 specimens of $P$. managuensis were sampled, with the highest total length frequencies between classes of 130 and $150 \mathrm{~mm}$. From the specimens sampled, 141 were female $(68-240 \mathrm{~mm}$ $T L, \bar{x}=153.71 \mathrm{~mm} T L, S D=21.73 \mathrm{~mm} \mathrm{TL})$, 95 were male $(78-230 \mathrm{~mm} \mathrm{TL}, \bar{x}=145.87 \mathrm{~mm} \mathrm{TL}$, $\mathrm{SD}=28.34 \mathrm{~mm} \mathrm{TL}$ ) and 284 could not have their sex identified, especially those smaller than $100 \mathrm{~mm}$ $T L$, which were considered immature (Figure 2). Due to the low number of identified adult by sex and the difficulties in determining sex for small individuals, the analysis was realized with grouped data, with both sexes together.

Total weight of the sample varied between 0.34 and $160.73 \mathrm{~g}$. The weight-length relationship yielded the following equation: $T W=0.00003 T L^{2.9004}\left(r^{2}=0.9868\right)$ (Figure 3A). When testing for possible differences between allometry coefficients by $\chi^{2}$, a significant difference was noticed $(P=0.0033)$, confirming the negative allometry for the sample. The total length-standard length relationship was described by the equation: $T L=1.9181+1.2657^{*} S L\left(r^{2}=0.9888\right)$ (Figure 3B).

The $L_{50}$ estimated through the model by King (1995) was $140.68 \mathrm{~mm}$ TL (95\% confidence interval $=137.58 / 144.45 ; \mathrm{SD}=1.81 \mathrm{~mm}$ ) (Figure 4A), while the $L_{s c}$ resulted in $130.88 \mathrm{~mm}$ $T L(95 \%$ confidence interval $=129.78 / 134.56$; $\mathrm{SD}=1.21 \mathrm{~mm})$ (Figure $4 \mathrm{~B})$ with the method described by Freitas et al. (2016). Length at maturity for the species was considered as the average length between both methods ( $135.78 \mathrm{~mm} \mathrm{TL}$ ).

Through the modal progression analysis of monthly length frequency distributions, two six-monthly cohorts were identified (Figure 5). Maximum theoretical length estimated for the species was $341.4 \mathrm{~mm} T L$, with a growth coefficient of 0.84 . The estimated $t_{0}$ was -0.035 year. With these parameters, the species reaches $123.65 \mathrm{~mm}$ during the first 6 months of life, with a monthly growth rate of $20.61 \mathrm{~mm}$, decreasing to $12.45 \mathrm{~mm} /$ month afterwards between 6 months and 1 year and to $8.18 \mathrm{~mm} / \mathrm{month}$ between the ages of 1 and 1.5 years (Figure 6).

Age structure of $P$. managuensis varied between 0.05 and 1.41 year $(\bar{x}=0.53$ year, $\mathrm{SD}=0.23$ year), with the majority of individuals aged between 0.4 and 0.8 year (Figure 6). Age at sexual maturity varied between 0.48 and 0.53 year $(\bar{x}=0.51$ year, $\mathrm{SD}=0.03$ year $)$, and fishing recruitment happens at 0.7 year, with the majority of the sample (72.64\%) being comprised of adult individuals (Figure 7).

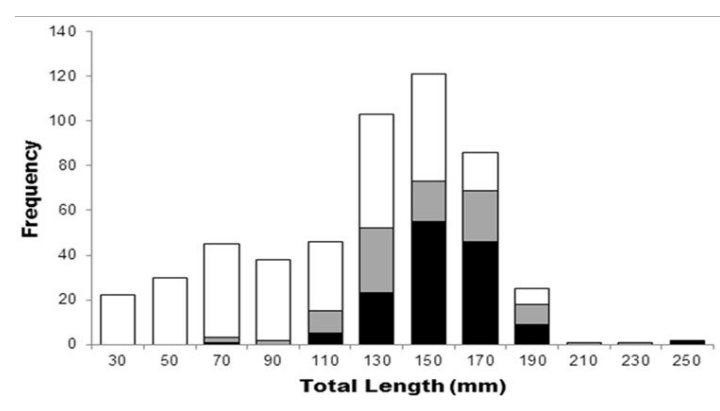

Figure 2. Total length frequency distribution for female (black), male (gray) and unidentified (white) specimens of $P$. managuensis at the Saco I dam, Pernambuco-Brazil
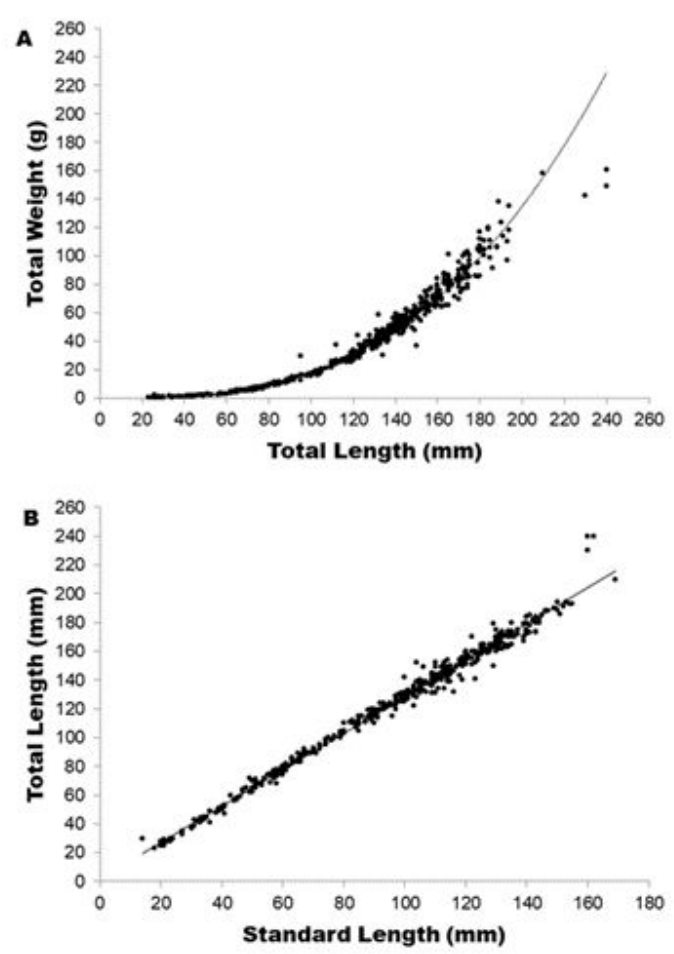

Figure 3. Total weight-total length relationship (A) and total length-standard length relationship (B) for P. managuensis at the Saco I dam, Pernambuco-Brazil 


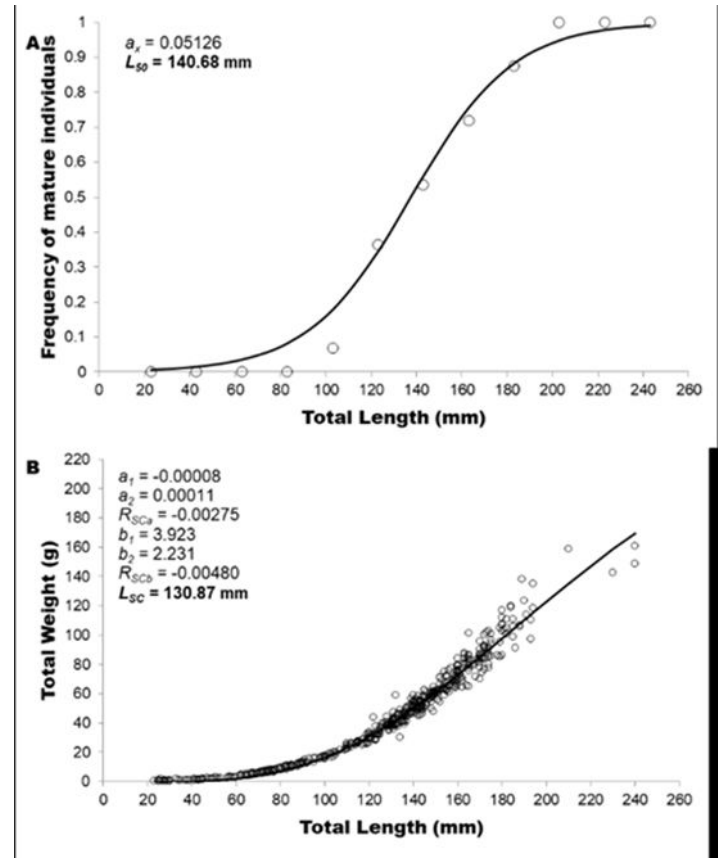

Figure 4. Proportion of mature (adult) by total length class (A) and Total length-total weight relationship according to Fontoura et al. (2010) (B) for P. managuensis at the Saco I dam, Serra Talhada-PE

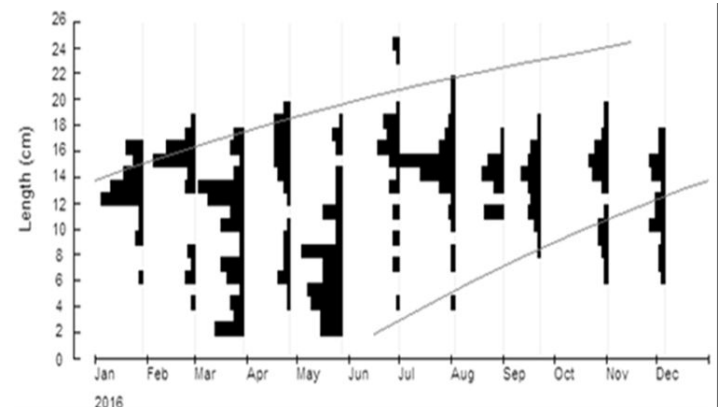

Figure 5. Frequency distribution by monthly length classes with estimated cohorts (blue lines) for $P$. managuensis at the Saco I dam, Pernambuco-Brazil.

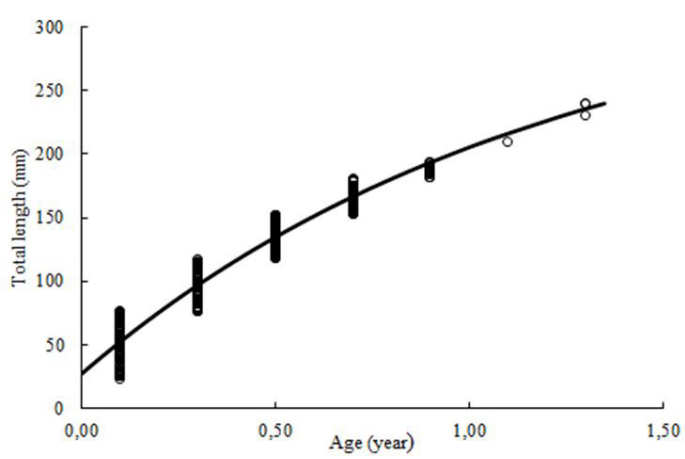

Figure 6. Growth curve according to the von Bertalanffy model for $P$. managuensis at the Saco I dam, Pernambuco-Brazil

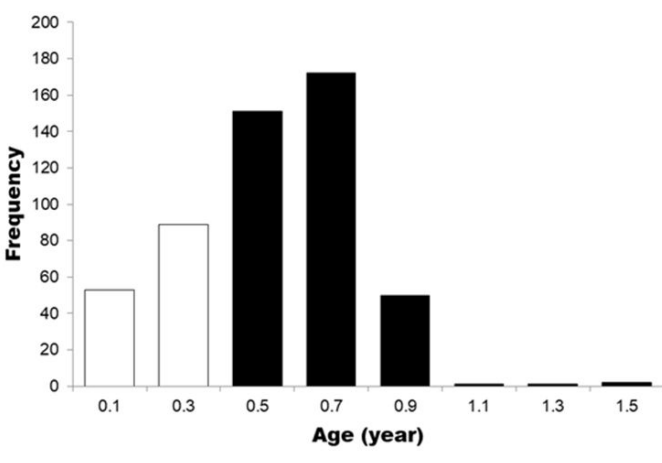

Figure 7. Age structure for the P. managuensis population at the Saco I dam, Serra Talhada-PE. White and black columns represent young and adult individuals, respectively.

Table 1. Natural mortality rates (M) for P. managuensis, at the Saco I dam, Serra Talhada-PE.

\begin{tabular}{lc}
\hline \multicolumn{1}{c}{ Author } & Natural Mortality $(\boldsymbol{M})$ \\
\hline Hoenig (2005) & 3.04 \\
Pauly (1980) & 1.53 \\
Rikhter \& Efanov (1976) & 2.24 \\
Mean & $\mathbf{2 . 2 7}$ \\
\hline
\end{tabular}

Natural mortality rates $(M)$ varied from 1.53 to 3.04, with a mean of 2.27 (Table 1), compatible with fastgrowing, early-maturing, short-lived fish species.

\section{Discussion}

The population of $P$. managuensis in the Saco I dam demonstrated adaptation to the biological conditions of the study site, presenting growth and reproduction strategies consistent with invasive species, establishing themselves in the place, since it does not present a natural predator, and would not have to theoretically compete for space and food. Conditions that favor its development and propagation, with behavior similar to that already registered in the literature in other countries that was introduced. The rapid growth strategy, associated with the annual average of the local temperature, made it possible to sample individuals with shorter lengths, but physiologically active for reproduction. As noted, Saco I dam's P. managuensis population showed lower lengths (169 mm SL) than those reported by Bussing (2002) in its native environment of $220 \mathrm{~mm}$ standard length. The same happens when comparing it to other non-native cichlid species (Table 2). Consequently, existing variations in length distributions can be influenced by the time since introduction and the characteristics that make up the ecosystems where species were analyzed (Gomiero \& Braga, 2003). 
Table 2. Maximum length $\left(T L_{\max }\right)$, von Bertalanffy growth parameters $\left(L_{\infty}, k\right.$ and $\left.t_{0}\right)$ in growth studies for cichlid species estimated through length frequency distributions.

\begin{tabular}{llcccccc}
\hline \multicolumn{1}{c}{ Author } & \multicolumn{1}{c}{ Species } & $\boldsymbol{T L}_{\max }(\mathbf{m m})$ & $\boldsymbol{L}_{\infty}(\mathbf{m m})$ & $\boldsymbol{k}\left(\mathbf{a n o} \mathbf{-}^{-1}\right)$ & $\boldsymbol{t}_{\boldsymbol{o}}$ (years) & Country & Native \\
\hline Jiménez-Badillo (2006) & Oreochromis aureus & 305.0 & 444.0 & 0.74 & 0.01 & Mexico & No \\
Jiménez-Badillo (2006) & Cichla Piquiti & 543.0 & 572.0 & 0.40 & -0.34 & Brazil & No \\
Gomiero et al. (2010) & C. kelberi & 548.0 & 577.0 & 0.35 & -0.39 & Brazil & No \\
Gomiero et al. (2010) & C. kelberi & 422.0 & 445.0 & 0.61 & -0.23 & Brazil & No \\
Campos \& Freitas (2010) & C. monoculus & 510.0 & 535.5 & 0.38 & - & Brazil & Yes \\
King \& Etim (2004) & Tilapia mariae & 284.5 & 304.0 & 0.40 & - & Nigeria & Yes \\
Present study & Parachromis & 240.0 & 341.4 & 0.84 & -0.10 & Brazil & No \\
& managuensis & & & & & & \\
\hline
\end{tabular}

The kind of allometry verified for the species through the weight-length relationship contributes to the knowledge on its morphology, providing parameters for comparison with other populations (Montenegro et al., 2011). The type of allometry verified indicates a greater increase in length than in weight, providing evidence of growth strategy, which may be related to the stages of maturity. There is no set pattern, in which the growth constant most likely varies depending on environmental conditions, available resources, and the species biology.

Knowledge regarding average length at first maturity $\left(L_{50}\right)$ for the species is among the information that contribute to understanding the reproductive strategy, as well as management strategies and minimum capture lengths (Gurgel et al.,2011). Based on that, the estimated length at maturity for $P$. managuensis is similar to that described by Farid et al. (2000) for Parachromis dovii (138 mm TL) when using the same method in Costa Rica, and the estimated for P. managuensis in Indonesia (136.4 mm TL), obtained based on the Spearman-Karber method in Udupa (1986), which considers maturing individuals as mature (Hamiyati et al., 2019). The size of the first maturation varies between regions, motivated by environmental differences. In addition, the size of maturity demonstrates plasticity even at the intrapopulation level. (Duponchelle \& Panfili, 1998).

Species reproductive strategy can indicate an allocation of energy resources to growth, with the objective of reaching the size at sexual maturity faster (Fonteles-Filho, 2011). Against this background, knowledge on the $L_{50}$ of $P$. managuensis, as well as other attributes already mentioned, can contribute to future studies that propose to analyze possible advantages this parameter can offer about native species in the region. Besides the already mentioned characteristics, the identified length pattern $\left(L_{50}\right)$ demonstrates that this possibly occurs due to changes in patterns of individual energy investment, reflected on the weight-length relationship (Freitas et al., 2016).

From the methods used to determine length at first maturity, the one by Freitas et al. (2016) shows the effective beginning of sexual maturity, as it portrays physiological oscillations resulting from patterns of energy investment per length phase. Therefore, it is the most recommended and the length that marks the beginning of maturity corresponds to $130.88 \mathrm{~mm}$. The estimated number of cohorts for the species in this study was similar to that found by Farid et al. (2000) for the P. dovit population in Costa Rica: 3 cohorts. In that case, it should be noted that $P$. managuensis would not reach more than 2 years because of the quick growth already shown, adequate to the number of cohorts identified, with a six-monthly periodicity. This biological aspect agrees with the assumption that species with fast life cycles tend to reach a small size and exhibit low longevity (Fonteles-Filho, 2011).

The observed length variations for the $\mathrm{L}_{\infty}$ between $P$. managuensis and other species (Table 2) results from particularities of abiotic factors and interaction-derived pressures (Werner \& Gilliam, 1984; Jones, 1992). For these reasons, when comparing the growth of $P$. managuensis in the present study to other cichlid species, it is noted that the observed variation arises from divergences between maximum sizes observed (Table 2). When analysing $K$ values for $P$. managuensis and the ones estimated for different cichlid species, it is possible to note that non-native species tend to exhibit a faster growth when compared to native species (Table 2). According to Sparre \& Venema (1998), such differences are acceptable, since growth parameters can vary between species, in the same way as between springs for the same species. Still according to the authors, the growth coefficient is specifically related to metabolic rates, and vary 
according to temperature and species biological factors, contributing to the present variations.

For the age and growth curve of $P$. managuensis at the Saco I dam, it was noticed that the highest growth occurs until the first year of age. Thus, according to Pannela (1974), the decrease in growth rate in subsequent years occurs for tropical fishes, after first maturity, since a large part of the energy is targeted to reproduction. A fast growth pattern was noticed based on the analysis of the growth parameters for the studied species. In particular, the growth rate observed for $P$. managuensis was certainly influenced by the characteristic climate of the semiarid, with a high evaporation rate playing a significant role in the organization and function of aquatic ecosystems, reflecting high temperature rates (Chellappa et al., 2009). This factor directly affects fish metabolism and growth, since the average temperature reported for the study site is $27.29{ }^{\circ} \mathrm{C}$. Eventually, the growth rate for $P$. managuensis in its natural habitat would presumably be different, since the climate representative to Costa Rica is milder, with an average annual temperature of $24.15^{\circ} \mathrm{C}$ and a more pronounced rainy season (CRRH, 2008), factors that contribute to a slow growth (Jones, 1992; Sparre \& Venema, 1997).

In general, natural mortality rates for tropical fishes like $P$. managuensis tend to be higher due to multiple factors, such as predation and diseases that affect the population in different ways according to age (Pauly, 1998; Sparre \& Venema, 1997). Mortality parameters for $P$. managuensis were higher than those established for other cichlid species (Ruffino \& Isaac, 1995; Mahmoud et al., 2013), even though it is considered as resistant and fast-adapting to abiotic factors such as oxygen concentration and $\mathrm{pH}$ fluctuations. Furthermore, it also exhibits parental care, which contributes to reduce its mortality (Berghe \& Mckaye, 2001; Agasen et al., 2006; Rosana et al., 2006).

Based on the biological information obtained in this study and depletion of the native species Hoplias malabaricus based on local fisher's reports, we relate these factors to the presence of $P$. managuensis. Its abundance in the dam has increased over the last 6 years, while $H$. malabaricus disappeared from the dam within three years, and $P$. managuensis is now fished and consumed in place of the tilapia (O. niloticus), with a marked fisheries decline. The presence of $P$. managuensis in the Saco I dam represents a risk to the native population of the trahira (Hoplias malabaricus), hindering its growth. Since the introduced species has high resistance to abiotic oscillations and has eating habits similar to those of the native species, competing for food and space. The $H$. malabaricus species in these conditions has a tendency to lose space due to its slow growth, which favors the dissemination of the introduced species (Barbieri, 1989; Martins, Rego, Pinese, 2009; Novaes \& Carvalho, 2011). Under these conditions, $P$. managuensis is also considered a real threat to fish fauna in the Rio Doce Basin, in Minas Gerais (Barros et al., 2012).

In summary, $P$. managuensis showed a tendency for fast growth. However, it is advised that more precise studies must be carried out using hard structures (otolith) to better adjust the growth parameters, since in these structures it is possible to evaluate the real growth and age of the species since the larval stage, from the analysis of the growth rings. In addition, more studies aiming to improve knowledge on the biology of the species together with its mortality parameters in order to contribute towards the knowledge on possible impacts caused by $P$. managuensis as an introduced species in Brazil.

\section{Acknowledgements}

We are grateful to the components of the Laboratório de Ecologia e Sistemática de Peixes (LAESP) of the Universidade Federal Rural de Pernambuco (UFRPE) of the Unidade Acadêmica de Serra Talhada (UAST) Washington Fernando Dantas de Sena and Sérgio Roberto Temótio Filho, for having contributed with the collections during the study period. To the Laboratório de Dinâmica de Populaçóes Marinhas (DIMAR) at UFRPE, in the figure of Professor Dr. Rosângela Paula Teixeira Lessa, for offering the space and support necessary to carry out this work. And the Coordenação de Aperfeiçoamento de Pessoal de Nível Superior (CAPES) for the scholarship granted during the master's degree.

\section{Ethical statement}

The care and use of experimental animals are in compliance with [Brazilian Institute of the Environment and Renewable Natural ResourcesIBAMA] laws, guidelines and animal welfare policies approved by [Chico Mendes Institute for Biodiversity Conservation-ICMBio, with license reference number 24709-1].

\section{References}

AGASEN, E.V., CLEMENTE, J.P., ROSANA, M.R. and KAWIT, N.S. Biological Investigation of Jaguar Guapote Parachromis managuensis (Gunther) in Taal 
Lake, Philippines. Journal of Environmental Science and Management, 2006, 9(2), 20-30.

AGÊNCIA PERNAMBUCANA DE ÁGUAS E CLIMA - APAC. Bacias Hidrográficas [online]. Recife, PE: APAC, 2018 [viewed 15 June 2019] Available from: http://www.apac.pe.gov.br/pagina. php?page_id=5\&subpage_id $=20$

AMADOR, D.A.L.E., KUSUNOKI, A.T.W., CARRIÓ, E.C.G., PÉREZ, R.B. and RODRÍGUEZ, P.C. Peces Invasores de Agua Dulce en la Región de la Laguna de Términos, Campeche. Unacar Tecnociencia, 2009, 3, 11-28.

BARBIERI, G. Dinâmica de Reprodução e Crescimento de Hoplias malabaricus (Bloch, 1794) (Osteichthyes, Erythrinidae) da Represa do Monjolinho, São Carlos/SP. Revista Brasileira de Zoologia, 1989, 6(2), 225-233. http://dx.doi.org/10.1590/S010181751989000200006 .

BARBOSA, J.E.L., MEDEIROS, E.S.F., BRASIL, J., CORDEIRO, R.S., CRISPIM, M.C.B. and SILVA, G.H.G. Aquatic systems in semi-arid Brazil: limnology and management. Acta Limnologica Brasiliensia, 2012, 24(1), 103-118. http://dx.doi. org/10.1590/S2179-975X2012005000030.

BARBOSA, J.M., MENDONÇA, I.T.L. and PONZI JÚNIOR, M. Comportamento Social e Crescimento em Parachromis managuensis (Gunther, 1867) (Pisces, Cichlidae): uma espécie introduzida no Brasil. Revista Brasileira de Engenharia de Pesca, 2006, 1(1), 65-74. http://dx.doi.org/10.18817/repesca.v1i1.18.

BARROS, L.C., SANTOS, U., ZANUNCIO, J.C. and DERGAM, J.A. Plagioscion squamosissimus (Sciaenidae) and Parachromis managuensis (Cichlidae): A threat to native fishes of the Doce River in Minas Gerais, Brazil. PLoS One, 2012, 6(7), 1-5. http://dx.doi.org/10.1371/journal.pone.0039138. PMid:22720053.

BERGHE, E.P. and MCKAYE, K.R. Reproductive success of maternal and biparental care in a Nicaraguan cichlid fish, Parachromis dovii. Journal of Aquariculture and Aquatic Sciences, 2001, 9, 49-65.

BITTENCOURT, L.S., SILVA, U.R.L., SILVA, L.M.A. and DIAS, T.D. Impact of the invasion from Nile tilapia on natives Cichlidae species in tributary of Amazonas River, Brazil. Biota Amazônia, 2014, 4(3), 88-94. http://dx.doi.org/10.18561/2179-5746/ biotaamazonia.v4n3p88-94.

BUSSING, W.A. Peces de las aguas continentales de Costa Rica-Freshwater fishes of Costa Rica. 2. ed. San José, Costa Rica: Editorial de la Universidad de Costa Rica, 2002, 504 p.

CAMPOS, C. P. and FREITAS, C.E.C. Curva de Crescimento do Tucunaré Cichla monoculus Spix \& Agassiz, 1831 do Lago Grande de Manacapuru, Amazonas, Brasil. Revista Brasileira de Engenharia de Pesca, 2010, 5(1), 1-9.
CHELLAPPA, S., BUENO, R.M.X., CHELLAPPA, T., CHELLAPPA, N.T. and VAL, V.M.F.A. Reproductive seasonality of the fish fauna and limnoecology of semi-arid Brazilian servoirs. Limnologica, 2009, 39(4), 325-329. http://dx.doi. org/10.1016/j.limno.2009.06.003.

COLLARES-PEREIRA, M.J. and COWX, I.G. The role of catchment scale environmental management in freshwater fish conservation. Fisheries Management and Ecology, 2004, 11(3-4), 303-312. http://dx.doi. org/10.1111/j.1365-2400.2004.00392.x.

COMITÉ REGIONAL DE RECURSOS HIDRÁULICOS - CRRH. Clima, variabilidade y cambio climático em Costa Rica [online]. San José, Costa Rica: CRRH, 2008 [viewed 28 June 2008]. Available from: http://users.clas.ufl.edu/prwaylen/ geo3280articles/el_clima_variabilidad_y_cambio_ climatico_en_cr_version_final.pdf

DUPONCHELLE, F. and PANFILI, J. Variations in age and size at maturity of female Nile tilapia, Oreochromis niloticus, populations from manmade lakes of Côte d'Ivoire. Environmental Biology of Fishes, 1998, 52(4), 453-465. http://dx.doi. org/10.1023/A:1007453731509.

FARID, A., TABASH, B. and EMILIER, G.S. A management plan for the sport fishery of Parachromis dovii (Pisces: Cichlidae) in Hule lake, Costa Rica. Revista de Biología Tropical, 2000, 48(2-3), 473-485. PMid:11354954.

FONTELES-FILHO, A.A. Oceanografia, biologia e dinâmica populacional de recursos pesqueiros. 2. ed. Fortaleza: Expressão Gráfica Editora, 2011, 464 p.

FONTOURA, N.F., JESUS, A.S., LARRE, G.G. and PORTO, J.R. Can length/weight relationship predict size at first maturity? A case study with two species of Characidae. Neotropical Ichthyology, 2010, 8(4), 835-840. http://dx.doi.org/10.1590/S167962252010005000013.

FRANÇA, E.J., ALMEIDA, C.A.C., NETO, M.S.A., SANTOS, R.E., MAGALHÃES, A.L.B., ELDEIR, A.C.A. and SEVERI, W. Novelty on the market, novelty in the environment: The invasion of non-native fish jaguar guapote (Perciformes) in northeastern Brazil. Neotropical Biology and Conservation, 2017, 12(1), 12-18. http://dx.doi. org/10.4013/nbc.2017.121.02.

FREITAS, T.M.S., ALMEIDA, V.H.C., MONTAG, L.F.A. and FONTOURA, N.F. Predicting size at first sexual maturity from length/weight relationship: A case study with na Amazonian catfish. Neotropical Ichthyology, 2016, 14(4), 150-152. http://dx.doi. org/10.1590/1982-0224-20150152.

FROESE, R. Cube law, condition factor and weightlength relationships: history, meta-analysis and recommendations. Journal of Applied Ichthyology, 2006, 22(4), 241-253. http://dx.doi.org/10.1111/ j.1439-0426.2006.00805.x. 
GAYANILO, J.R., SPARRE, F.C.P. and PAULY, D. The FAO-ICLARM Stock Assesment Tools (FISAT) user's guide. Rome: FAO, 1997, 262 p. FAO Computerized information Series (Fisheries), no. 8.

GOMIERO, L.M. and BRAGA, F.M.S. Relação pesocomprimento e fator de condição para Cichla ocellaris e Cichla monolucus (Perciformes, Cichlidae) no reservatório de Volta Grande, Rio Grande - MG/ SP. Acta Scientiarum. Biological Sciences, 2003, 25(1), 79-86. http://dx.doi.org/10.4025/actascibiolsci. v25i1.2119.

GOMIERO, L.M., CARMASSI, A.L., RONDINELI, G.R., VILLARES JUNIOR, G.A. and BRAGA, F.M.S. Growth and mortality of Cichla spp. (Perciformes, Cichlidae) introduced in Volta Grande Reservoir (Grande River) and in a small artificial lake in Southeastern Brazil. Brazilian Journal of Biology = Revista Brasileira de Biologia, 2010, 70(4), 1093-1101. http://dx.doi.org/10.1590/S151969842010000500027. PMid:21180920.

GUBIANI, E.A., RUARO, R., RIBEIRO, V.R., EICHELBERGER, A.C.A., BOGONI, R.F., LIRA, A.D., CAVALli, D., PIANA, P.A. and GRAÇA, W.J. Non-native Fish species in Neotropical freshwaters: how did they arrive, and where did they come from? Hydrologia, 2018, 817(1), 57-69. http:// dx.doi.org/10.1007/s10750-018-3617-9.

GURGEL, L.L., VERANI, J.R., CÂMARA, F.R.A., BARROS, N.H.C. and CHELLAPPA, S. Ecologia reprodutiva de Cichlasoma orientale (Osteichthyes: Cichlidae), um peixe endêmico do semiárido brasileiro. Biota Amazônia, 2011, 1(2), 36-44. http:// dx.doi.org/10.18561/2179-5746/biotaamazonia. v1n2p36-44.

HAMIYATI, I., BATU, D.T.F.L., and YONVITNER. Biological reproduction aspects of jaguar guapote (Parachromis managuensis) in Penjalin reservoir Brebes-Central Java, Indonesia. Journal of Biodiversity and Environmental Sciences, 2019, 14(4), 8-13.

HOENIG, J.M. Empirical use of longevity data to estimate mortality rates. SEDAR33- RD17. North Charleston: SEDAR, 2005, 8 p.

HUXLEY, J.S. Constant differential growth-ratios and their significance. Nature, 1924, 114(2877), 895896. http://dx.doi.org/10.1038/114895a0.

I N T E R-A M ER I C A N B I O DIVERSIT Y INFORMATION NETWORK. 2019 [viewed 15 June 2019]. Available from: bd.institutohorus.org. br/www/.

JIMÉNEZ-BADILLO, L. Age-growth models for tilapia Oreochromis aureus (Perciformes, Cichlidae) of the Infiernillo reservoir, Mexico and reproductive behavior. Revista de Biologia Tropical, 2006, 54(2), 577-588. http://dx.doi.org/10.15517/rbt. v54i2.13923. PMid:18494324.
JONES, C.M. Development and application of the otolith increment technique. In: D.K. STEVENSON and S.E. CAMPANA, eds. Otolith microstructure examination and analyses. Ottawa: Department of Supply and Services, 1992, pp. 1-11. Canadian Special Publication Aquatic Sciences, vol. 117.

KING, M. Fisheries biology: Assessment and managment. Oxford: Fishing News Books, Blackwell Scientific Publications Ltd., 1995.

KING, R.P. and ETIM, L. Reproduction, growth, mortality and yield of Tilapia mariae Boulenger 1899 (Cichlidae) in a Nigerian rainforest wetland stream. Journal of Applied Ichthyology, 2004, 20(6), 502-510. http://dx.doi.org/10.1111/j.14390426.2004.00545.x.

LE CREN, E.D. The length-weight relationship and seasonal cycle in gonad weight and condition in theperch (Perca fluviatilis). Journal of Animal Ecology, 1951, 20(2), 201-219. http://dx.doi. org/10.2307/1540.

LEAL, I.R., TABARELLI, M. and SILVA, J.M.C. Ecologia e conservação da Caatinga. 2. ed. Recife. Ed. Universitária da UFPE, 822p, 2005.

LIMA, S.M.Q., RAMOS, T.P.A., DA SILVA, M.J., and DE SOUZA ROSA, R. Diversity, Distribution, and Conservation of the Caatinga Fishes: Advances and Challenges. In: J.M.C. Silva, I.R. Leal, M. Tabarelli (eds) Caatinga. Springer, 2017. http://dx.doi. org/10.1007/978-3-319-68339-3_4

MAGALHÂES, A.L.B. and JACOBI, C.M. E-commerce of freshwater aquarium fishes: potential disseminator of exotic species in Brazil. Acta Scientiarum. Biological Sciences, 2010, 32(3), 243-248. http://dx.doi. org/10.4025/actascibiolsci.v32i3.3919.

MAHMOUD, H.H., EZZAT, A.A., EL-SAYED, A.L.I.T. and EL SAMMAN, A. Fisheries management of cichlid fishes in Nozha Hydrodrome, Alexandria, Egypt. Egyptian Journal of Aquatic Research, 2013, 39(4), 283-289. http://dx.doi.org/10.1016/j. ejar.2013.12.006.

MARTINS, J.M.E., REGO, A.C.L. and PINESE, J.F. Determinação da Idade e Crescimento de Hoplias malabaricus (Bloch, 1794) (Characiformes, Erythrinidae) na Represa de Capim Branco I, Rio Araguari, MG. Revista Brasileira de Zoociências, 2009, 11(3), 261-268.

MONTENEGRO, A.K.A., TORELLI, J.E.R., CRISPIM, M.C. and MEDEIROS, A.M.A. Estrutura Populacional e Alimentar de Steindachinerina notanota, Miranda Ribeiro, 1937 (Actinopterygii, Characiformes, Curimatidae) no Açude Taperoá II, na região do semi- árido da Paraíba, Brasil. Acta Limnologica Brasiliensia, 2011, 23(3), 233-244. http:// dx.doi.org/10.1590/S2179-975X2012005000003.

MOURA, M.S.B., GALVINCIO, J.D., BRITO, L.T.L., SOUZA, L.S.B., SÁ, I.I.S. and SILVA, T.G.F. 
Clima e água de chuva no semi-árido. In: L.T.L. BRITO, M.S.B. MOURA and G.F.B. GAMA, eds. Potencialidades da água de chuva no semiárido brasileiro. Petrolina: Embrapa Semiárido, 2007, pp. 37-59.

NOVAES, J.L.C. and CARVALHO, E.D. Populations structure and stock Assessment of Hoplias malabaricus (Characiformes: Erythrinidae) caugth by artesanal fishermen in river-reservoir transition área in Brazil. Revista de Biología Tropical, 2011, 59(1), 71-83. PMid:21513193.

PANNELA, G. Otolith growth patterns: an aid in age determination in temperate 359 and tropical fishes. In: T.B. BAGENAL, ed. Ageing of fishes. Surrey: Unwin Brothers, 1974, pp. 28-39.

PATOKA, J., MAGALHÁES, A.L.B., KOUBA, A., FAULKES, Z., JERIKHO, R. and VITULE, J.R.S. Invasive aquatic pets: failed policies increase risks of harmful invasions. Biodiversity and Conservation, 2018, 27(11), 3037-3046. http:// dx.doi.org/10.1007/s10531-018-1581-3.

PAULY, D. A selection of simple of simple methods for the assessement of tropical fish stocks. FAO Fisheries Circular, 1980, 729, 54

PAULY, D. Gill size and temperature governing factors in fish growth: a generalization of von Bertalanffy's growth formula. Berichte aus dem Institut für Meereskunde an der Christian-Albrechts-Universität Kiel,, 1979, 63, 171.

PAULY, D. Tropical fishes: patterns and propensities. Journal of Fish Biology, 1998, 53, 1-17. http://dx.doi. org/10.1111/j.1095-8649.1998.tb01014.x.

PAULY, D., DAVID, N. and ELEFAN, I. A Basic program for the objective extraction of growth parameters from length-frequency data. Berichte der Deutschen wissenschaftlichen commission fur meeresforschung, 1981, 28(4), 205-211.

RAMOS, T.P.A., LIMA, J.A.S., COSTA, S.Y.L., SILVA, M.J., AVELLAR, R.C. and SILVA, L.O. Continental ichthyofauna from the Paraíba do Norte River basin pretransposition of the São Francisco River, Northeastern Brazil. Biota Neotropica, 2018, 18(4), 2-10. http:// dx.doi.org/10.1590/1676-0611-bn-2017-0471.

RIKHTER, V.A. and EFANOV, V.N. On one of the approaches to estimation of natural mortality of fish populations. International Commission for the Northwest Atlantic Fisheries, 1976, 6, 12.

ROSANA, M.R., AGASEN, E.V., VILLANUEVA, L.S., CLEMENTE, J.P., KAWIT, N.S. and VEGA, J.T. Status and Economic Impact of Parachromis managuensis in Taal Lake, Philippines. Journal of Environmental Science and Management, 2006, 9(2), 1-19.

RUFFINO, M.L., and ISAAC, V.J. Life cycle and biological parameters of several Brazilian Amazon fish species. Naga, the ICLARM Quarterly, 1995, 18, 41-45.

SPARRE, P. and VENEMA, S.C. Introdução à avaliação de mananciais de peixes tropicais Parte1: Manual. Roma: FAO, 1997. FAO Documento técnico sobre as Pescas.

SPARRE, P., and VENEMA, S. C. Introduction to tropical fish assessment. Part 1. Manual. Rome: FAO, 1998. FAO Fisheries Technical Paper.

UDUPA, K.S. Statistical method of estimating the size at first maturity in fishes. Fishbyte, 1986, 4, 8-10.

VAZZOLER, A.E.A.M. Biologia da Reprodução de Peixes Teleósteos: teoria à prática. Maringá: EDUEM, 1996.

VITULE, J.R.S. and PRODOCIMO, V. Introdução de espécies não nativas e invasôes biológica. Estudos de Biologia, 2012, 34(83), 225-237. http://doi.10.7213/ estud.biol.7335.

VITULE, J.R.S. Introdução de peixes em ecossistemas continentais brasileiros: revisão, comentários e sugestóes de açóes contra o inimigo quase invisível. Neotropical Biology and Conservation, 2009, 4(2), 111 122. http://dx.doi.org/10.4013/nbc.2009.42.07.

VON BERTALANFFY, L. A quantitative theory of organic growth. Human Biology, 1938, 10, 181-213.

WERNER, E.E. and GILLIAM, J.F. The ontogenetic niche and species interactions in size-structured populations. Annual Review of Ecology and Systematics, 1984, 15(1), 393-42. http://dx.doi.org/10.1146/ annurev.es.15.110184.002141.

Received: 31 March 2020 Accepted: 08 September 2020

Associate Editor: Gustavo Henrique Gonzaga da Silva. 